\title{
PEMANFAATAN TANAH KAS DESA DALAM BENTUK PERJANJIAN SEWA MENYEWA
}

\author{
Oleh \\ Zakiah Noer*, Muchyidin** \\ * Fakultas Hukum, Universitas Gresik \\ Email : Zakiahnoer12@gmail.com \\ ** Fakultas Hukum, Universitas Gresik \\ Email : muchyidin06@gmail.com
}

\begin{abstract}
ABSTRAK
Dalam penyelenggaraan pemerintahan, pelaksanaan pembangunan dan khususnya pelayanan kepada masyarakat Pemerintah Desa memerlukan sumber pendapatandanayang memadai yaitu salah satunya dengan pemanfaatan Tanah Kas Desa.Mengenai pemanfaatan aset desa Peraturan Menteri Dalam Negeri Nomor 1 Tahun 2016 tentang Pengelolaan Aset Desa dalam Pasal 11 ayat (2) menyatakan bahwa pemanfaatan aset desa terbagi menjadi empat, yaitu sewa menyewa, pinjam pakai, kerjasama pemanfaatan, bangun guna serah atau bangun serah guna. Selanjutnyadalam Pemanfaatan aset desa harus ditetapkan dalam Peraturan Desa yang diatur dalam pasal (3) ayat 1. Apabila pemerintah Desa dalam melaksanakan memanfaatkan aset desa yang dimiliki, harus memiliki Peraturan Desa. Jika pemerintah Desa ingin memanfaatkan aset desa dalam bentuk sewa yang dimiliki, harus memiliki Peraturan Desa. Tindakan hukum pemerintah desa yang menyewakan dengan pihak lain dalam memanfaatkan aset desanya, maka pemerintah bertindak sebagai badan hukum dan tunduk kepada hukum privat. Maka pemerintah desa jika melakukan perjanjian dalam betuk sewa haruslah taat pada Pasal 1320 KUH Perdata sebagai syarat sahnya suatu perjanjian yaitu kesepakatan, kecakapan, hal tertentu dan kausa yang halal.
\end{abstract}

Kata kunci :Perjanjian, Sewa Menyewa, Tanah Kas Desa

\begin{abstract}
In improving Village Welfare, the village government in government administration, development implementation and especially services to the community requires adequate funding sources, one of which is the use of Village Treasury Land. Thus, the Regulation of the Minister of Home Affairs Number 1 of 2016 concerning Village Asset Management in Article 11 paragraph (2) states that the utilization of village assets is divided into four, namely leasing, borrowing and using, joint utilization, building for handover or building for handover. Furthermore, Article (3) states that the utilization of village assets must be stipulated in a Village Regulation. So if the Village government wants to take advantage of the village assets it has, it must have a Village Regulation. So if the village government wants to take advantage of village assets in the form of rent it has, it must have a Village Regulation. The legal action of the village government that rents out with other parties in utilizing its village assets,
\end{abstract}


the government acts as a legal entity and is subject to private law. So if the village government makes an agreement, it must comply with Article 1320 of the Civil Code as a condition for the validity of the agreement, namely agreement, skills, certain things and lawful causes.

Keywords: Agreement, Lease, Village Treasury Land 


\section{A. PENDahuluan}

Salah satu kekayaan desa yang dapat dikelola oleh pemerintah desa adalah aset desa agar terwujudnya kesejahteraan masyarakat desa sesuai dengan harapan pemerintah yang tertuang dalam Pembukaan UndangUndang Dasar 1945.

Dalam pengelolaan aset desa yang dimiliki oleh desaPemerintah menerbitkan Peraturan Menteri Dalam Negeri Republik Indonesia Nomor 1 Tahun 2016 Pasal 7 menyebutkan bahwa salah satu pengelolaan aset Desa adalah dengan Pemanfaatan Aset desa. Selanjutnya Pemanfaatan aset desa itu meliputi, sewa, pinjam pakai, kerjasama pemanfaatan, bangun guna serah atau bangun serah guna.

Dari Peraturan Pemerintah diatas Kekayaan asli desa sendiri dibagi menjadi 11 macam yaitu menurut Peraturan Menteri Dalam Negeri tersebut salah satunya adalah tanah kas desa. Selainkekayaan asli desa berupa tanah kas desa ada juga yang berupa pasar desa pasar hewan, tambatan perahu, bangunan desa, pelelangan ikan yang dikelola oleh desa, pelelangan hasil pertanian, pemandian umum, hutan milik desa dan mata air milik desa.

Salah satu hal pemanfaatan Tanah Kas Desa dapat dilakukan dengan bentuk sewa menyewa. Perjanjian Sewa menyewa terhadap Tanah Kas Desa dilaksanakan dengan tidak merubah status hak kepemilikan aset desa dan jangka waktu perjanjian sewa tanah kas desa paling lama 3 (tiga) tahun dan dapat diperpanjang.

Pemanfaatan tanah kas desa dalam bentuk sewa-menyewa masih dirasa sangat penting termasuk didalamnya adalah sewa menyewa tanah. Hal ini dapat dilihat dalam Kitab UndangUndang Hukum Perdata pasal 1548 disebutkan bahwa: Sewa menyewa adalah suatu persetujuan dengan mana pihak yang satu mengikatkan dirinya kepada pihak yang lainnya untuk memberikan suatu kenikmatan dari barang yang di sewakan, selama waktu tertentu dan dengan pembayaran harga sewa, yang pihak tertentu belakangan itu disanggupi pembayarannya.

Atas pelaksanaan Pemerintah desa dalam hal pemanfaatan aset desa dalam bentuk sewa kenyataannya menunjukkan ada yang mengalami kerugian dan ada juga yang mengalalmi keuntungan itulah peneliti tertarik untuk mengkaji permasalahan terutama tentang pengelolaan aset dalam bentuk perjanjian sewa menyewa yang pemanfaatannya dikelola oleh pihak lain.

Yang menjadi permasalahan yaitu apakah Pemanfaatan aset desa dalam bentuk perjanjian sewa menyewa yang di buat para pihak sesuai dengan peraturan perundang- undangan yang berlaku.

Adapun tujuan dilakukannya penelitian ini adalah untuk menganalisis tentang pemanfaatan aset desa khususnya pemanfaatan aset desa dalam bentuk sewa menyewa tanah kas desa. Berdasarkan latar belakang masalah dan tujuan penelitian yang telah diuraikan diatas, maka penulis akan membahasnya lebih lanjut dalam penulisan ini dengan judul

Pemanfaatan Tanah Kas Desa Dalam Bentuk Perjanjian Sewa Menyewa"

\section{B. METODEPENELITIAN}

Di dalam penelitian ini, penulis menggunakan metode penelitian yuridis normatif yaitu dilakukan dengan cara menelaah teori-teori hukum, konsep-konsep hukum, asasasas hukum serta mengkaji peraturan perundang-undangan yang berhubungan dengan pokok permasalahan yang telah dirumuskan dalam penelitian ini. Untuk mencari jawaban atas pokok permasalahan 
dalam penelitian ini, Penulis menggunakan pendekatan masalah yaitu Pendekatan Konseptual (Conceptual Approach), Pendekatan Perundang-undangan

(Statute

Approach), dan

PendekatanPerbandingan

(ComparativeApproach).

\section{PEMBAHASAN}

\section{Pengertian Perjanjian}

Perjanjianadalah bentuk persetujuan dari dua pihak atau lebih, yang saling berjanji untuk mengikatkan diri untuk melakukan sesuatu. Oleh karena itu, perjanjian ini sangat penting, sehingga dalam pelaksanaannya hendaknya selalu dibuat dalam bentuk tertulis agar memiliki kekuatan hukum dan kepastianhukum dalam melakukan suatu perjanjian.

R. Subekti memberikan pendapatnya sebagai berikut : Suatu perjanjian adalah suatu peristiwa di mana seorang berjanji kepada orang lain atau dimana dua orang itu saling berjanji untuk melaksanakan suatu hal. Perjanjian ini menimbulkan suatu perikatan antara dua belah pihak yang membuat suatu perjanjian. Dalam bentuknya, perjanjian ini berupa kesanggupan yang diucapkan atau ditulisdan berupa suatu rangkaian perikatan yang mengandung

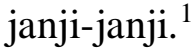

\section{Pengertian Sewa Menyewa}

Pasal 1548 KUHPerdata memberikan pengertian mengenai persetujuan para pihak yang mengikatkan diri, di mana pihak satu menyerahkan kenikmatan suatu barang dengan ketentuan waktu, dan kesepakatan mengenai harga sewa oleh para pihak. dari rumusan diatas bahwa perjanjian sewa menyewa dapat dikatakan suatu perjanjian konsensuil dimana perjanjian tersebut telah mengikat dan sah pada saat terpenuhinya kata sepakat, yaitu

${ }^{1}$ R. Subekti, Hukum Perjanjian, Cet. 21, PT. Intermasa, Jakarta, 2005, hal. 1. mengenai barang yang disewa dan harga sewanya.

Dalam kegiatan sewa-menyewa yang terjadi ialah dalah satu pihak memberikan kenikmatan suatu barang, dan pihak lainnya membayar atas kenikmatan barang yang disewanya.

\section{Kewajiban Hak Sewa Menyewa}

Dalam perjanjian sewa menyewa Pihak yang menyewakan mempunyai kewajiban yaitu:(1) Menyerahkan barang yang disewakan kepada pihak penyewa.(2) Memelihara barang yang disewakan sedemikian rupa hingga barang tersebut dapat digunakan untuk keperluan yang dimaksudkan. (3) Memberikan kepada pihak penyewa kenikmatan dari objek perjanjian sewamenyewa selama berlangsungnya persewaan. $^{2}$

Selanjutnya pihak yang penyewa diwajibkan, selama waktu sewa, menyuruh lakukan pembetulanpembetulan pada barangnya yang disewakan sesuai yang diperlukan, terkecuali pembetulan-pembetulan kecil yang menjadi kewajiban pihak penyewa. Sebagaimana disebutkan dalam Pasal 1551 dan 1552 KUHPerdata bahwa, pihak yang menyewakan juga diwajibkan menanggung si penyewa terhadap semua kerusakan dari barang yang disewakan sedemikian rupa, meskipun pihak penyewa tidak mengetahuinya pada waktu dibuatnya perjanjian sewa menyewa. Jika kerusakan tersebut mengakibatkan suatu kerugian bagi pihak penyewa, maka kepada pihak yang menyewakan diwajibkan memberikan ganti rugi.

\section{Resiko Dalam Perjanjian Sewa Menyewa}

Pengertian risiko adalah kewajiban untuk bertanggung jawab atau kerugian yang telah disebabkan oleh suatu

${ }^{2}$ R.Subekti, Aneka Perjanjian, PT. Citra Aditya Bakti, Bandung, 2014,hal. 54 
kejadian atau peristiwa diluar kesalahan yang dilakukan oleh salah satu pihak yang menimpa terhadap barang yang menjadi objek perjanjian tersebut.

Dalam perjanjian sewa menyewa tentu pelaksaannya tidak selalu sesuai dengan apa yang telah diperjanjikan sebelumnya antara para pihak. Di dalam prakteknya, banyak sekali peristiwa-peristiwa yang berisiko dalam melaksanakan suatu perjanjian terjadi hambatan-hambatan para pihak untuk melaksanakan hak dan kewajibannya masing-masing. Dalam pasal 1533 K.U.H.Perdata mengatur tentang resiko dalam perjanjian sewa menyewa yang dimana dalam pasal tersebut membahas selama waktu sewa barang yang disewakan sama sekali musnah atau hilang karena suatu kejadian yang tidak disengaja maka perjanjian sewa menyewa tersebut gugur demi hukum.

\section{Berakirnya Perjanjian Sewa Menyewa}

Berakirnya suatu perjanjian sewa menyewa menurut KUHPerdata Pasal 1570 menyebutkan bahwa jika sewa dibuat dengan tulisan, maka sewa itu berakir demi hukum, apabila waktu yang telah ditentukan telah lampau, tanpa diperlakukanya sesuatu pemberhentian.

Sewa-menyewa juga dapat berkahir dalam waktu tertentu yang diperjanjikan secara lisan. Pasal 1571 K.U.H.Perdata menjelaskan tentang perjanjian sewa dalam jangka waktu tertentu, tetapi diperbuat seacara lisan. Perjanjian seperti ini tidak berakhir tepat pada waktu yang telah diperjanjikan, namun ia berakhir setelah adanya pemberitahuan dari salah satu pihak tentang kehendak mengakhiri sewa-menyewa. Dan perjanjian tersebut harus memperhatikan jangka waktu yang layak menurut kebiasaan setempat.
Artinya dalam penghentian perjanjian sewa-menyewa secara lisan pengakhiran sewa harus memperhatikan jangka waktu penghentian (opzeggingstermijn) sesuai dengan kebiasaan setempat. Batas waktu perjanjian antara pengakhiran dan penghentian inilah yang disebut dengan jangka waktu penghentian.

Selanjutnya mengenai pengakhiran sewa-menyewa baik secara tertulis ataupun lisan yang tidak ditentukan batas waktu berakhirnya yaitu, seacara umum dapat dipahami penghentian atau berakhirnya perjanjian sewamenyewa berjalan sampai pada saat yang dianggap pantas oleh kedua belah pihak. ${ }^{3}$

Pengertian ini dapat menjadi pedoman karena undang-undang sendiri tidak mengatur bagaimana cara pengakhiran perjanjian sewa tanpa batas waktu. Undang-undang hanya mengatur perihal pengakhiran perjanjian sewamenyewa seacra tertulis dan lisan yang di dalamnya berisi kesepakatan tentang batas waktu sewa-menyewa.

\section{Mengulang Sewakan}

Pasal 1559 K.U.H.Perdata ayat (1) menyebutkan pihak penyewa melarang untuk mempersewakan ulang barang atau objek perjanjian sewa-menyewa kepada pihak ketiga tanpa persetujuan sebelumnya. Maka artinya, mempersewakan suatu barang atau objek sewaan diijinkan hanya saja harus ada kesepakatan ketika mengakirisuatu perjanjian yang di buat oleh para pihak.

Menyewakan ulang barang atau objek sewaan berarti pihak penyewa semula mempersewakan lagi barang yang disewanya itu atas namanya sendiri kepada orang lain yaitu pihak ketiga. Baik untuk sebagian maupun untuk

\footnotetext{
${ }^{3}$ Yahya Harahap, Segi-Segi Hukum Perjanjian, Alumni, Bandung, hal.240
} 
seluruhnya. Maka dari itu, hubungan sewa-menyewa kemudian terjadi antara pihak penyewa dalam perjanjian awal dengan pihak ketiga. Artinya pihak penyewa mempersewakan ulang barang atau objek perjanjian (wederver huur), yang berbeda konteksnya dengan tindakan menyerahkan sewa kepada pihak lain (zijn huur aan een andere afstan). Dalam hal ini pihak ketiga langsung berhubungan dengan pihak yang menyewakan atau si pemilik barang atau objek perjanjian secara langsung. ${ }^{4}$

\section{Bentuk Perjanjian Sewa Menyewa}

Pada perjanjian yang termasuk sebagai perjanjian formil, tidak dipenuhinya ketentuan hukum tentang misalnya format atau bentuk perjanjian, cara pengesahan perjanjian, ataupun carapembuatan perjanjian, sebagaimana ketentuan peraturan perundang-undangan, mengakibatkan perjanjian tersebut batal demi hukum. Para ahli hukum memberikan pengertian perjanjian formil sebagai perjanjian yang tidak hanya didasarkan adanya suatu kesepakatan para pihak, tetapi oleh undang-undang juga disyaratkan adanya formalitas tertentu yang harus dipenuhi supaya perjanjian tersebut sah demi hukum.

Berdasarkan pengertian akta sebagaimana dijelaskan diatas, akta digolongkan menjadi dua bentukdiantaranya : (a) Akta Ontentik (b) Akta Dibawah Tangan.

Akta otentik adalah akta yang dibuat oleh Notaris dan Pejabat lainya yang diberi wewenang oleh penguasa, sesuai ketentuan-ketentuan yang telah ditetapkan, baik dengan maupun tanpa bantuan dari yang berkepentingan, yang mencatat apa yang dimintakan untuk dimuat di dalamnya oleh yang berkepentingan. Akta otentik mempunyai kepastian orang dan

\footnotetext{
${ }^{4}$ Yahya Harahap, Op. Cit., hal. 231-
}

kepastian tanggalnya, sedangkan Pasal 1868 K.U.H.Perdata menyatakan bahwa akta otentik adalah suatu akta yang dalam bentuk yang ditentukan oleh Undang-Undang, dibuat oleh atau dihadapan pegawai-pegawai umum yang diberikan kewenangan/kuasa untuk itu ditempat di mana akta tersebut dibuat.

Akta di bawah tangan ialah akta yang dibuat untuk pembuktian oleh para pihak tanpa bantuan dari seorang pejabat, jadi hanya antara para pihak yang berkepentingan saja. Dalam ketentuan K.U.H.Perdata pasal 1875 menyebutkan bahwa suatu tulisan di bawah tangan yang diakui oleh orang terhadap siapa tulisan itu hendak dipakai, atau yang dengan cara menurut undang-undang dianggap sebagai diakui, memberikan terhadap orangorang yang menandatanganinya, bukti yang sempurna seperti suatu akta otentik, dengan demikian berlaku juga ketentuan pasal 1871 untuk tulisan itu. Mengenai kepastian hukumnya, akta di bawah tangan akan mempunyai kekuatan pembuktian baik lahir, formil maupun materiil apabila tanda tangan didalam akta tersebut diakui oleh para pihak dan para saksi. ${ }^{5}$

\section{Kedudukan Tanah Kas Desa}

Kedudukan dan pengelolaan tanah desa secara teknis diatur dalam Peraturan Menteri Dalam Negeri Nomor 1 Tahun 2016. Pasal 1 ayat (26) Peraturan Menteri Dalam Negeri Nomor 1 Tahun 2016 Tentang Pengelolaan Aset Desa menyatakan bahwa Tanah Desa adalah tanah yang dikuasai atau dimiliki oleh Pemerintah Desa sebagai salah satu sumber pendapatan asli desa dan untuk kepentingan sosial.

Tanah desa menurut Peraturan Menteri Dalam Negeri Nomor 1 Tahun 2016 merupakan aset desa yang berbentuk

\footnotetext{
${ }^{5}$ Kohar A, Noktariat Berkomunikasi, Alumni, Bandung, 1984, hal. 86.
} 
kekayaan desa. Tetapi penyebutannya bukan tanah desa melainkan tanah kas desa. Artinya ada perbedaan pengertian antara tanah desa dalam Pasal 1 ayat (26) dan tanah desa dalam Pasal 2 ayat(2) huruf [a] Permendagri Nomor 1 Tahun 2016. Dalam ketentuan tersebut dapat diartikan tanah desa merupakan tanah yang dikuasai oleh desa sebagai sumber pendapatan asli desa dan kepentingan sosial untuk Masyarakat desa. Sedangkan tanah kas desa merupakan kekayaan asli desa yang dapat berfungsi untuk memberikan sumber pendapatan desa.

\section{Pemanfaatan Aset Desa}

Pemanfaatan aset desa merupakan tindakan terhadap penggunaan aset desayang baik di sisi lain juga meningkatkan pelayanan terhadap masyarakat desa, menghasilkan pendapatan dan juga dapat mensejahterakan masyakat desa. Pemanfaatan aset dalam struktur pendapatan desa termasuk dalam rincian objek hasil pemanfaatan atau pendayagunaan Pengelolaan Aset Desa dalam upaya meningkatkan kesejahteraan kekayaan asli desa yang tidak dapat dipisahkan.

Manfaat dari tanah kas desa tersebut dapat menghasilkan pendapatan desa dan dapat membantu pertumbuhan masyarakat desa dalam hal perekonomian. Dan pemerintah desa agar melakukan sebuah pembinaan kepada masyarakat di desa untuk mengatahui semua aset desa yang dimili. Sehingga masyarakat desa dan pemerintah bisa saling berkesinambungan untuk saling bekerja sama dalam pemanfaatan aset desa tersebut supaya untuk menambah pendapat di desa yang bertujuan untuk mensejahterakan desa dan menunjang kebutuhan desa.

Dalam hal pemanfaatan Tanah Kas Desa dapat dilakukan dengan cara sewa. Sewa terhadap Tanah Kas Desa dapat dilakukan dengan tidak mengubah hakstatus kepemilikan aset desa dan jangka waktu sewa paling lama 3 (tiga) tahun dan dapat diperpanjang. Selain pemanfaatan dengan cara sewa ada juga pemanfaatan dengan cara pinjam pakai, kerjasama pemanfaatan dan bangun guna atau bangun serah guna.

Sewa tanah kas desa adalah pemanfaatan barang milik desa oleh pihak lain dalam jangka waktu yang sudah ditentukan dan menerima harga yang disepakati. Objek sewa dalam hal ini adalah berupa tanah yang status haknya milik Pemerintahan Desa. Tujuan sewa tanah kas desa adalah supaya tanah milik desa yang belum atau tidak dipergunakan dalam tugas pokok dan serta mencegah penggunaan oleh pihak lain secara tidak sah. Penyewaan tanah milik desa dilakukan sepanjang tidak merugikan desa dan tidak mengganggu pelaksanaan tugas dan fungsi penyelenggaraan pemerintah desa dan juga sebagai bentuk kekayaan asli desa guna menunjang pendapatan asli desa.

Dalam sewa tanah kas desa Jangka waktu sewa paling lama 3 (tiga) tahun sejak ditandatanganinya perjanjian. Jangka waktu dapat diperpanjang. Sewa dalam barang milik desa yang berupa tanah desa dilakukan atas persetujuan dari kepala desa dan Perangkat Desa desa setempat.

\section{Pengelolaan Tanah Kas Desa}

Pengelolaan tanah kas desa termasuk dalam pengelolaan hasil kekayaan asli desa. Hasil pemanfaatan kekayaan desa merupakan pendapatan atau penerimaan desa. Penerimaan desa wajib seluruhnya disetorkan ke bagian keuangan desa. Kekayaan asli desa yang berupa tanah kas desa tidak diperbolehkan merubah status hak dan pelepasan hak kepemilikan kepada pihak lain, kecuali dipergunakan untuk kepentingan umum. 
Pelepasan hak kepemilikan tanah desa untuk kepentingan umum dapat dilakukan setelah mendapat ganti rugi sesuai harga yang dibutuhkan Pemerintah desa dengan memperhatikan nilai jual objek pajak dan harga pasar sesui zona tanah. Penggantian ganti rugi yang berupa uang harus digunakan untuk membeli tanah lain yang lebih baik dan berlokasi di desa setempat.

Pelepasan hak kepemilikan tanah desa tersebut ditetapkan dengan keputusan tertulis dari kepala desa. Keputusan kepala desa diterbitkan setelah mendapat persetujuan Badan Permusyawaratan Desa dan Perangkat lainya, tokoh masyarakat dan mendapat izin tertulis dari bupati/walikota. ${ }^{6}$

Kepala Desa di sini adalah sebagai pemegang kekuasaan pengelolaan kekayaan asli milik Desa. Dalam melaksanakan pengelolaan kekayaan milik Desa, kepala desa dapat menguasakan sebagian kekuasaannya kepada perangkat desa lainnya. Pengelolaan kekayaan milik desa merupakan rangkaian kegiatan mulai dari pengadaan, perencanaan, pemanfaatan, penggunaan, pengamanan, pemeliharaan, pelaporan, penghapusan, pemindah tanganan, penatausaan, penilaian, pembinaan, pengawasan, dan pengendalian kekayaan milik desa.

\section{Mekanisme Pemanfaatan Aset Desa}

Aset desa merupakan barang milik desa yang berasal dari kekayaan asli desa, diperoleh atau dibeli atas beban anggaran pendapatan desa dan belanja desa( APBDesa) atau perolehan hak lainnya yang sah. Salah satu aset desa yang dapat dikelola adalah berupa tanah kas desa. Tanah kas desa

\footnotetext{
${ }^{6}$ Nurcholis, Pertumbuhan dan Penyelenggaraan Pemerintahan Desa, liberty, Yogyakarta, 2011, hal 81
}

merupakan tanah milik desa yang pengelolaannya dapat dimanfaatkan oleh pihak lain atau maupun pemerintah desa sendiri, namun dengan catatan tanah tersebut statusnya masih hak milik desa.

Tanah kas desa menjadi sumber pendapatan desa yang penggunaanyadan pemanfaatanya untuk urusan kepentingan pemerintahan desa. Pengelolaan tanah kas desa haruslah berdasarkan dari hasil musyawarah desa. Dalam musyawarah ini keterlibatan masyarakat sangatlah penting yaitu mulai dari unsur Badan Permusyawatan Desa, Rukun Tetangga, dan Rukun Warga serta tokoh masyarakat yang ada di dalam desa tersebut.

Kepala Desa adalah Pemegang kekuasaan aset desa yang menguasakan sebagian kekuasaannya kepada perangkat desa. Dalam hal memanfaatkan aset desa ini haruslah didasarkan pada asas kepentingan umum, fungsional, kepastian hukum, keterbukaan, efisiensi, efektivitas, akuntabilitas, dan kepastian nilai ekonomi. Kepala desa dalam memanfaatkan aset desa dilarang merugikan kepentingan umum.

Selanjutnya dalam melaksanakan pemanfaatan aset desa tersebut haruslah diatur di dalam Peraturan Desa. Mengenai pemanfaatan aset desa berupa sewa diperjelas dalam Pasal 12, yang menyatakan sebagai berikut : Pemanfaatan aset desa berupa sewa tidak diperbolehkan merubah status kepemilikan desa, Jangka waktu penyewaan paling lama 3 (tiga) tahun dan dapat diperpanjang, Penyewaan aset desa haruslah didasarkan pada perjanjian yang memuat poin berikut ini :Para pihak yang terlibat dalam perjanjian. Objek perjanjian sewa menyewa. Jenis, luas atu jumlah barang, besaran sewa dan jangka waktu sewa. Tanggung jawab penyewa atas 
biaya operasional dam pemeliharaan jangka waktu sewa. Hak dan kewajiban oara pihak yang terkait dalam perjanjian. Keadaan diluar kemampuan para pihak dan Persyaratan lain yang dianggap perlu.

\section{Akibat Hukum Jika Pemanfaatan Aset Desa Tidak Sesuai Dengan Mekanisme Yang Ada}

Pemerintahan adalah subyek hukum atau pendukung hak-hak dan kewajiban-kewajiban. Sebagai subyek hukum, pemerintah melakukan berbagai tindakan, baik tindakan nyata maupun tindakan hukum. Tindakan hukum merupakan tindakan yang dimaksudkan untuk mewujudkan hak dan kewajiban.

Akibat hukum yang lahir dari tindakan hukum adalah akibat-akibat yang memiliki relevansi dengan hukum. Dengan kata lain, akibat-akibat hukum itu dapat berupa hal-hal sebagai berikut :Jika menimbulkan beberapa perubahan hak, kewajiban, atau kewenangan yang ada. Jika menimbulkan perubahan kedudukan hukum bagi seseorang atau obyek yang ada. Jika terdapat hak-hak, kewajiban, kewenangan, atau status tertentu yang ditetapkan.

Setiap tindakan hukum pemerintah harus didasarkan pada peraturan perundang-undangan yang berlaku, maka dengan kata lain tindakan hukum pemerintah tidak diperbolehkan menyimpang atau bertentangan dengan peraturan yang bersangkutan, yang dapat menyebabkan akibat-akibat hukum yang muncul itu batal atau dapat dibatalkan. ${ }^{7}$

Kedudukan hukum pemerintah diatur dengan dua hukum yang berbeda yaitu hukum publik dan hukum privat dan akan menimbulkan akibat hukum yang berbeda beda pula.jika pemerintah

\footnotetext{
${ }^{7}$ Ridwan, HR, Hukum Administrasi Negara, UII Press Yogyakarta, Yogyakarta, 2003, hal 83 .
}

bertindak tidak dalam kualitas pemerintah maka hukum privatlah yang berlakuMaka Jika pemerintah bertindak dalam kualitasnya sebagai pemerintahan, maka hanya hukum publiklah yang berlaku. Maka dari itu jika pemerintah berkedudukan dalam hukum privat maka ia tidak berbeda dengan pihak swasta yaitu tunduk pada hukum privat.

Pada tindakan hukum pemerintah di Desa ini, maka karena pemerintah desa bekerjasama dengan pihak lain dalam memanfaatkan aset desanya, maka pemerintah desa disini tunduk pada hukum privat. Maka apabila tindakan hukum pemerintah ini bertentangan dengan undang-undang yang berlaku maka dapat batal demi hukum.

Peraturan Pelaksana Undang- Undang Nomor 6 Tahun 2014 yairu Peraturan Pemerintah Republik Indonesia Nonor 43 Tahun 2014 menyebutkan dalam Pasal 110 ayat (2) bahwa Pengelolaan kekayaan milik Desa diatur dengan peraturan Desa yang berpedoman pada Peraturan Menteri. Begitu pula Pasal 11 ayat (3) Peratura Menteri Dalam Negeri Nomor 1 Tahun 2016 menyatakan jika dalam memanfaatkan aset Desa, pemerintah Desa harus menetapkan dalam Peraturan Desa.

Pemerintah desa disini melakukan perjanjian sewa dengan pihak lain untuk memanfaatkan aset desanya, maka perjanjiansewa yang dibuat dengan pihak lain dengan tidak adanya peraturan desa sebagai acuan perjanjian yang dilakukan dapat dibatalkan dan di perbaiki isiperjanjian.

\section{Efektivitas Hukum}

Hukum berfungsi untuk kepastian, keadilan dan kemanfaatan. Dalam praktik masyarakat dalam melakukan hukum di lapangan banyak pertentangan antara keadilan hukum dan kepastian hukum. Karena kepastian hukun dengan keadilan hukum sifatnya 
berbeda, sehingga ketika hakim memustukan suatu perkara secara penerapan undang-undang saja maka nilai keadilan itu tidak tercapai. Maka ketika melihat suatu permasalahan mengenai hukum setidaknya keadilan menjadi prioritas utama dalam penegakan. Karena hukum tidaklah semata-mata dilihat dari sudutpandang hukum tertulis saja.

Tolak ukur efektifitas hukum dalam penagakan hukum dibagi menjadi lima yaitu 1) Faktor Hukum yang berfungsi untuk memberikan tentang kepastian hukum, keadilan hukum dan pemanfaatan hukum, 2) Faktor penegakan hukum dalam fungsinya kepribadian atau mentalitas petugas penegak hukum memainkan peranan penting, apabila peraturan sudah baik.Sayangnya penegak hukum dalam melaksanakan wewenangnya sering timbul permasalahan karena sikap atau perlakuan yang dipandang melampui wewenang atau perbuatan lainnya yang dianggap melunturkan citra dan wibawa penegak hukum. Hal ini disebabkan oleh kualitas yang sangat rendah dari aparat penegak hukum tersebut. 3) Faktor fasilitas dan sarana pendukung Penegak hukum tidak dapat bekerja dengan maksimal, apabila tidak dilengkapi dengan alat-alat komunikasi yang proporsional dan kendaraan. Oleh karena itu sarana atau fasilitas memiliki peranan sangat penting didalam penegakan hukum. tanpa adanya saran atau fasilitas pendukung tersebut tidak akan mungkin penegak hukum menyamakan peranan yang seharusnya dengan peranan yang seharusnya. 4) Faktor Masyarakat Penegak hukum berasal dari masyarakat yang bertujuan untuk mencapai kedamaian didalam masyarakat. Setiap warga masyarakat atau kelompok sedikit banyaknya mempunyai kesadaran dalam mematuhi hukum. 5) Faktor Kebudayaan Kebudayaan pada dasarnya mencakup nilai-nilai yang mendasar hukum yang berlaku, nilai-nilai mana yang merupakan konsepsi-konsepsi yangabstrak mengenai apa yang dianggap baik (sehingga dituruti) dan apa yang dianggap buruk (sehingga dihindari).

\section{KESIMPULAN}

Pemanfaatan Aset Desa haruslah berdasarkan pada perundang-undangan yang berlaku, salah satu syaratnya yaitu dengan memiliki perdes terlebih dahulu sebelum memanfaatkan aset desanya. Setiap tindakan hukum pemerintah harus didasarkan pada peraturan perundang-undangan yang berlaku, jika tindakan hukum pemerintah tidak sesuai dengan perundangundangan yang berlaku maka dapat menyebabkan akibat hukum yaitu dapat dibatalkan dan di perbaiki isi perjanjian. Pemerintah Desa dalam melakukan pemanfaatan khusunya dalam perjanjian sewa menyewa harus berpedoman pada peraturan desa, jika tidak memiliki peraturan Desa, maka perjanjian yang dibuat oleh pemerintah desa dapat dibatalkan dan di perbaiki isi perjanjian. Dikarenakan tidak memenuhi syarat obyektif yaitu kausa yang halal. Karena pada dasarnya pemerintah desa dalam melakukan perjanjian tunduk pada hukum privat.

\section{E. DAFTAR BACAAN}

\section{Buku-buku}

A. Kohar., Noktariat Berkomunikasi, Alumni, Bandung, 1984

Harahap Yahya., Segi-Segi Hukum Perjanjian, Alumni, Bandung, 1982.

H.R Ridwan., Hukum Administrasi Negara, UII Pres, Yogyakarta, 2002

Nurcholis, Pertumbuhan dan Penyelenggaraan Pemerintahan Desa, liberty, Yogyakarta, 2011

Subekti. R, Hukum Perjanjian, PT. Intermasa, Jakarta, 2005. , Aneka Perjanjian, Cet. 11, PT. 
Citra Aditya Bakti, Bandung,2014.

Subekti dan Tjitrosudibio., $K U H$

Perdata dengan tambahan UUPA dan

UUP, Pradya Paramita, Jakarta, 1992.

Perundang-Undangan

K.U.H.Perdata (Burgerlijkwetboek);

Undang-Undang Nomor 6 Tahun 2014

Tentang Desa.

Peraturan Mentri Dalam Negeri Nomor 1 Tahun 2016 Tentang Pengelolaan Aset Desa 